\title{
Legenes ansvar i legaliseringsdebatten
}

\author{
Legene må delta i debatten om legalisering og regulering av illegale stoffer, da temaet ligger innenfor deres \\ ansvarsområde. Debatten handler ikke kun om å innføre legale, regulerte utsalgssteder eller om legeordine- \\ ring av stoffene. Noen faktorer har i høyeste grad med legenes virke i samfunnet og deres forhold til pasienter
} som bruker illegale stoffer å gjøre.

Medisinere har ansvar for å informere om positive og negative medisinske virkninger av illegale stoffer, på en nøytral måte. Dette trengs for å forbedre informasjonen om illegale stoffer i samfunnet vårt. Det forbudspolitiske klimaet har ført til at det jeg vurderer som pseudomedisinsk, uproporsjonert informasjon om stoffenes skadevirkninger har tilflytt publikum fra politiet, fra forbudsforkjempere med ikke-medisinskfaglig bakgrunn, fra medisinerne selv og fra politikerne. Dette skjer ikke bare gjennom mediedekningen av narkotikaspørsmål generelt, men i det siste også som en del av selve legaliserings- og reguleringsdebatten.

Som en reaksjon på skremselspropagandaen er det kommet motsvar fra legaliseringsbevegelsen. Til tider fremmer denne like pseudomedisinske argumenter om stoffenes positive virkninger som forbudsregimet har fremmet pseudomedisinske argumenter om skadevirkningene. Medisinerne må og skal ha det største ansvaret for å korrigere mytemakeriet som hersker nettopp fordi stoffene er illegale og fordi moralen ofte er kommet foran den medisinske kunnskapen innenfor forbudstenkningen.

I en kronikk i Tidsskriftet konkluderer Jørgen G. Bramness slik: «En liberalisering eller legalisering av cannabis lenkes ofte opp til et ønske om regulering av bruken gjennom offentlige ordninger. Man ønsker salg gjennom et rusmonopol. Om man går inn for en legalisering, tror jeg dette er en fornuftig utvikling. Men jeg tror ikke leger har en rolle i denne viktige forebyggende delen av en slik fremtid» (1). Bramness skal ha honnør for at han allikevel er i gang med å ta et ansvar i forhold til cannabis spesielt, der han på en nøytral måte gir god informasjon om stoffets medisinske virkninger og hvor langt forskningen er kommet.

\section{Legene møter illegale stoffer}

Leger må forholde seg til hvordan bruken av illegale stoffer har positive eller negative medisinske virkninger på pasienten og at behandlingstilbud i noen sammenhenger blir innskrenket fordi medisinene er illegale. Leger med pasienter i legemiddelassistert rehabilitering (LAR) blir berørt av legaliseringsproblematikken, da de i forbindelse med forbudslovgivningen er satt til å utføre mistillitsskapende kontrolltiltak, som urinprøvetaking og strenge henteordninger.

Samtidig må leger ofte ta avgjørelser ut fra retningslinjer som er skapt ikke bare ut fra medisinsk forsvarlighet, men også ut fra samfunnsmessige faktorer, som det å skulle forhindre lekkasje av LAR-medisiner. De møter også begrensninger i forskrivning av noen medisiner - fordi disse omfattes av narkotikalovgivningen. På bakgrunn av dette lever noen leger med medisinske samvittighetskvaler, og de som omgår retningslinjene, kan miste forskrivningsretten.

I forbindelse med bruk og besittelse av små mengder illegale stoffer, hovedsakelig cannabis, blir ungdommer under 25 år i Bergen politiet i Hordaland kaller ressurs-

\section{«Legene bør innse at narkotikaforbudet influerer på behand- lingstilbudet og dermed kan få helsemessige skadevirkninger for}

\section{pasientene»}

sterke som alternativ til straff tilbudt deltakelse i programmet Tidlig ute. Gjennom dette henvises de videre til helsehjelp og oppfølging med urinprøvekontroller. Muligens kan slik henvisning av ressurssterk, narkotikalovbrytende ungdom til helsehjelp komme i konflikt med rett til prioritert helsehjelp i pasientrettighetslovgivningen - fordi ikke-lovbrytende ungdommer med større hjelpebehov enn dem som blir tatt for cannabisrøyking, blir skviset bakover i køen. Dette kan for eksempel være ungdommer i ferd med å utvikle alkoholproblemer.

Legene bør innse at narkotikaforbudet influerer på behandlingstilbudet og dermed kan få helsemessige skadevirkninger for pasientene. Fersk forskning viser at det er en sterk tendens blant fastleger og leger i spesialisthelsetjenesten til ikke å etterspørre somatiske symptomer hos pasienter med kjent ruslidelse (2). Derfor forblir somatiske sykdommer ubehandlet. Dette tror jeg kan ha bakgrunn i tradisjonell stigmatiserende forbudstankegang med nulltoleranse for illegale rusmidler - legens oppmerksomhet blir skjøvet bort fra fysiske og psykiske lidelser og over på det å bekjempe bruken av stoff (3).

Leger må også forholde seg til pasienters selvmedisinering med illegale stoffer. Stof- fene har medisinske virkninger og bivirkninger som kan interagere med medisiner forskrevet av lege. Pasienten kan ha medisinsk gode begrunnelser for bruken.

\section{Varedeklarasjon kan forebygge dødsfall}

Selv om legene kun kan forholde seg til godkjente preparater når de forskriver, vil de måtte ta hensyn til pasientenes bruk av naturpreparater eller syntetiske stoffer som MDMA (ecstasy). Det bør derfor være $i$ legenes interesse at man ved en legalisering stiller høye krav til varedeklarasjon og best mulig oversikt over virkestoffer. Blir milde rusmidler som cannabis og ecstasy legalisert, vil slike varedeklarasjoner kunne avhjelpe problemene legene nå har med å vite hva slags stoffer pasienten har tatt det kan dreie seg om overdosering eller om samkjøring med medisiner de skal forskrive. Jeg mener at man ikke kan utelukke at naturlig forekommende cannabis eller syntetiske rusmidler med medisinsk virkning gjennom regulering kan få nøyaktige nok varedeklarasjoner til at de skal kunne godkjennes til medisinsk bruk.

Leger har en viktig rolle i det forebyggende arbeidet legalisering og regulering av illegale stoffer er. Varedeklarasjoner kan forebygge dødsfall og fremme bedre kontrollert medisinsk behandling av stoffbrukere. På bakgrunn av dette er cannabisdebatten et viktig anliggende for helsepersonell.

Annette Svae

annettesvae@gmail.com

Annette Svae (f. 1967) er konstituert leder i Foreningen for human narkotikapolitikk Hordaland.

Forfatter har fylt ut ICMJE-skjemaet og oppgir ingen interessekonflikter.

\footnotetext{
Litteratur

1. Bramness JG. Cannabis som medisin. Tidsskr Nor Legeforen 2015; 135: 252-3.

2. Dalen E, Holmen J, Nordahl HM. Somatisk helse hos pasienter ved en ruspoliklinikk. Tidsskr Nor Legeforen 2015; 135: 127-31.

3. Lien L, Huus SG, Morken G. Psykisk syke lever kortere. Tidsskr Nor Legeforen 2015; 135: 246-8.
}

Mottatt 4.3. 2015 og godkjent 13.3. 2015. Redaktør Hanne Støre Valeur.

Publisert først på nett. 